\title{
PAIRED ${ }^{14} \mathrm{C}$ AND ${ }^{230} \mathrm{Th} / \mathrm{U}$ DATING OF SURFACE CORALS FROM THE MARQUESAS AND VANUATU (SUB-EQUATORIAL PACIFIC) IN THE 3000 TO 15,000 CAL YR INTERVAL
}

\author{
Martine Paterne ${ }^{1,2} \bullet$ Linda K Ayliffe ${ }^{1,3} \cdot$ Maurice Arnold ${ }^{1,4} \bullet$ Guy Cabioch $^{5} \bullet$ \\ Nadine Tisnérat-Laborde ${ }^{1} \bullet$ Christine Hatté ${ }^{1}$ Eric Douville ${ }^{1}$ Edouard Bard ${ }^{6}$ \\ ABSTRACT. Paired radiocarbon and ${ }^{230} \mathrm{Th} / \mathrm{U}$ dating was performed on 13 surface corals from submerged reefs in the \\ Marquesas and from raised terraces in Vanuatu. The absolute ages of the corals analyzed ranged from 3000 to $15,000 \mathrm{cal} \mathrm{yr}$. \\ Estimates of the difference between the absolute and ${ }^{14} \mathrm{C}$ ages of these corals are in agreement with previous determinations \\ up until 11,500 cal yr. The resulting mean sea surface reservoir age $R$ is determined at $390 \pm 60 \mathrm{yr}$ for the Marquesas region \\ $\left(9^{\circ} \mathrm{S}\right)$, which is slightly higher than the $R$ value at $280 \pm 50 \mathrm{yr}$ for the Tahiti Islands $\left(18^{\circ} \mathrm{S}\right)$. Multiple ${ }^{14} \mathrm{C}$ analyses of 2 corals \\ from the Marquesas present scattered ${ }^{14} \mathrm{C}$ ages at $\sim 12,000$ and $\sim 15,100 \mathrm{cal}$ yr. This could be attributed to rapid changes of the \\ ${ }^{14} \mathrm{C}$ content of surface waters around the Marquesas Islands or to a subtle submarine diagenesis.
}

\section{INTRODUCTION}

Radiocarbon and/or ${ }^{230} \mathrm{Th} / \mathrm{U}$ dating of surface corals have mainly been used to quantify the timing and amplitude of sea-level fluctuations, and also to estimate the deviation between the ${ }^{14} \mathrm{C}$ and calendar $\left({ }^{230} \mathrm{Th} / \mathrm{U}\right)$ ages. Superimposed on the long-term ${ }^{14} \mathrm{C}$ variation over the past $40,000 \mathrm{cal} \mathrm{BP}$ (Stuiver et al. 1998; Edwards et al. 1993; Bard et al. 1990a, 1993, 1998; Voelker et al. 1993; Burr et al. 1998; Hughen et al. 1998, 2000; Kitagawa and van der Plicht 1998, 2000; Beck et al. 2000), short-term fluctuations have been recorded in both terrestrial and marine materials and are considered to be linked to changes of solar activity and of the global carbon cycle (Stuiver et al. 1998). In the marine environment, the modern oceanic circulation controls mixing of "old" waters from the deep ocean with surface ocean waters. This leads to latitudinal variations of the sea surface reservoir ages, $R$ (Bard 1988). As the oceanic circulation has changed in the past, so have the $R$ values at midto high latitudes (Bard et al. 1994; Sikes et al. 2000; Siani et al. 2001). Modern surface corals record seasonal to centennial ${ }^{14} \mathrm{C}$ changes of some $20-40 \%$, related to both the atmospheric ${ }^{14} \mathrm{C}$ and oceanic circulation changes (Druffel 1997; Burr et al. 1998; Guilderson and Schrag 1998). Substantial local intra-ocean variations in $R$ were also recently suggested at similar latitudes for the Pacific Ocean (in Stuiver et al. 1998; Goslar et al. 2002).

We present here the results of coupled ${ }^{14} \mathrm{C}$ and ${ }^{230} \mathrm{Th} / \mathrm{U}$ dating of surface corals, collected from raised terraces from Vanuatu (Cabioch and Ayliffe 2000) and from submerged reefs around the Marquesas Islands (Figure 1). The absolute ages obtained for these corals by ${ }^{230} \mathrm{Th} / \mathrm{U}$ dating ranged from 3000 to $\sim 15,000 \mathrm{cal}$ yr. The difference between the absolute and ${ }^{14} \mathrm{C}$ ages of these corals are compared to those found in previous studies (Figure 2) (Stuiver et al. 1998; Bard et al. 1990a, 1993, 1998; Edwards et al. 1993; Burr et al. 1998; Hughen et al. 1998, 2000). $R$ estimates from the Marquesas and Tahiti are directly compared in the time interval of 9000-11,000 cal yr.

\footnotetext{
${ }^{1}$ Laboratoire des Sciences du Climat et de l'Environnement, Domaine du CNRS, Avenue de la Terrasse, F-91198 Gif sur Yvette, France.

${ }^{2}$ Corresponding author. Email: Martine.Paterne@1sce.cnrs-gif.fr.

${ }^{3}$ Present address: Department of Geology and Geophysics, University of Utah, Salt Lake City, Utah 84112, USA.

${ }^{4}$ Unité Mixte de Service UMS 2572, CEA Saclay, F-91198 Gif sur Yvette, France.

${ }^{5}$ IRD (Institut de Recherche pour le Développement), B.P. A5, 98848 Nouméa cedex, New Caledonia.

${ }^{6}$ CEREGE, Université d'Aix-Marseille III, CNRS UMR-6635, Europôle de l'Arbois, BP80, 13545 Aix-en-Provence cdx4, France.
}

(C) 2004 by the Arizona Board of Regents on behalf of the University of Arizona Proceedings of the 18th International Radiocarbon Conference, edited by N Beavan Athfield and R J Sparks RADIOCARBON, Vol 46, Nr 2, 2004, p 551-566 


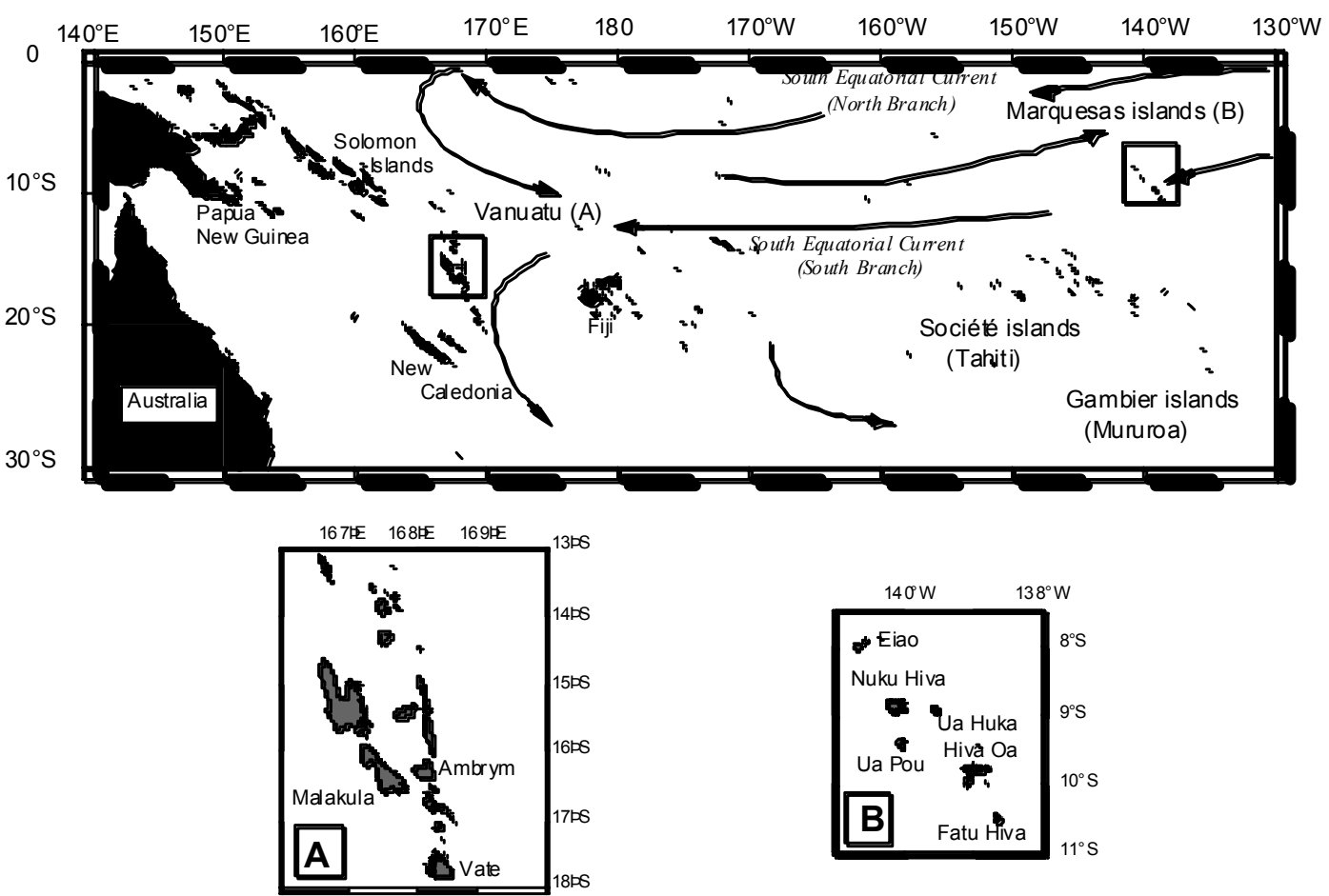

Figure 1 Sample locations; surface currents are also represented

\section{MATERIAL AND METHODS}

The surface corals (Porites sp.) were collected in the Marquesas Islands $\left(6^{\circ} \mathrm{S} ; 140^{\circ} \mathrm{W}\right)$ by dredging of submerged coral reefs in water depths greater than $86 \mathrm{~m}$ during the cruise conducted by the IRD in 1997 (Musorstom and Paleomarq), and in Vanuatu $\left(20^{\circ} \mathrm{S} ; 170^{\circ} \mathrm{E}\right)$ by direct sampling of emerged marine terraces raised by tectonic uplift (Figure 1). The corals from the Marquesas have been submerged in seawater since the time of their formation and have as a result most likely been preserved from major recrystallization/dissolution processes.

Coral specimens were cut into small slabs with cross-sectional areas between $4-6 \mathrm{~cm}^{2}$ and thickness of $\sim 0.1$ to $0.2 \mathrm{~cm}$. The shortest axis of these slabs were oriented parallel to the direction of growth. Growth bands were visible and continuous in the corals sampled. The slabs cut from each specimen probably represent some 1 to $15 \mathrm{yr}$ in time, given the range of possible growth rates documented by Priess (1997) of $\sim 2$ to $40 \mathrm{~mm}$ per yr for the Porites species. Each coral slab was then subsampled for $\mathrm{X}$-ray diffractometry $(\mathrm{XRD}),{ }^{14} \mathrm{C}$, and ${ }^{230} \mathrm{Th} / \mathrm{U}$ analyses. Coral samples having a magnesian calcite or pure calcite content lower than $2 \%$ were selected for dating with 1 exception (Table 1).

\section{${ }^{230} \mathrm{Th} / \mathrm{U}$ Dating}

The U/Th age determination follows the procedure by Cabioch and Ayliffe (2000). Exterior surfaces of corals samples were initially cleaned by physical abrasion with a dental drill bit. The coral samples were then further cleaned by ultrasound treatment and several rinses with quartz distilled (QD) water. $U$ and Th fractions were extracted and purified from coral samples using standard ion exchange chemistry as described by Stirling et al. (1995). The purified U and Th separates were loaded onto zone-refined Re filaments between 2 layers of colloidal graphite. Isotopes of $\mathrm{U}$ and $\mathrm{Th}$ 


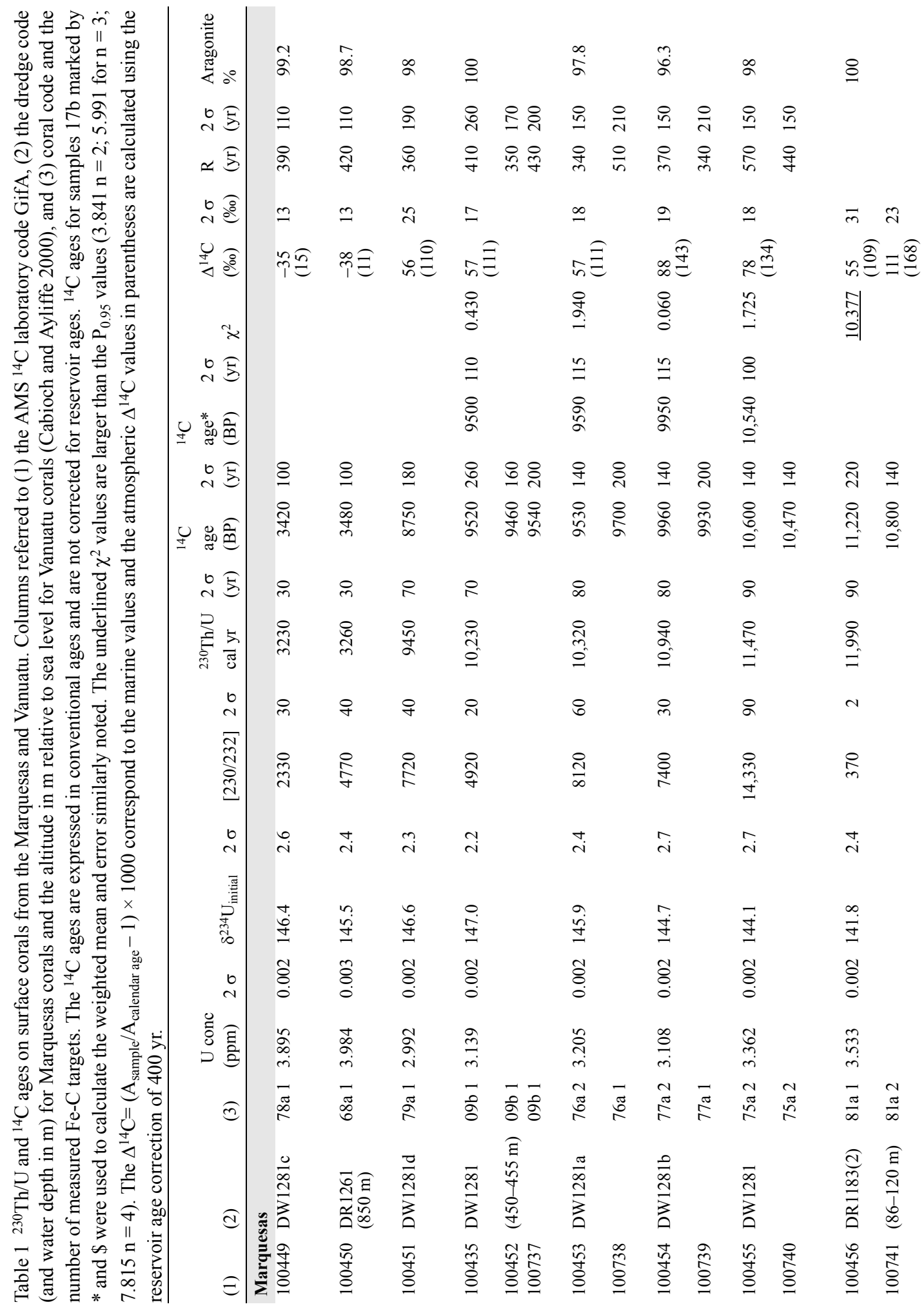


M Paterne et al.

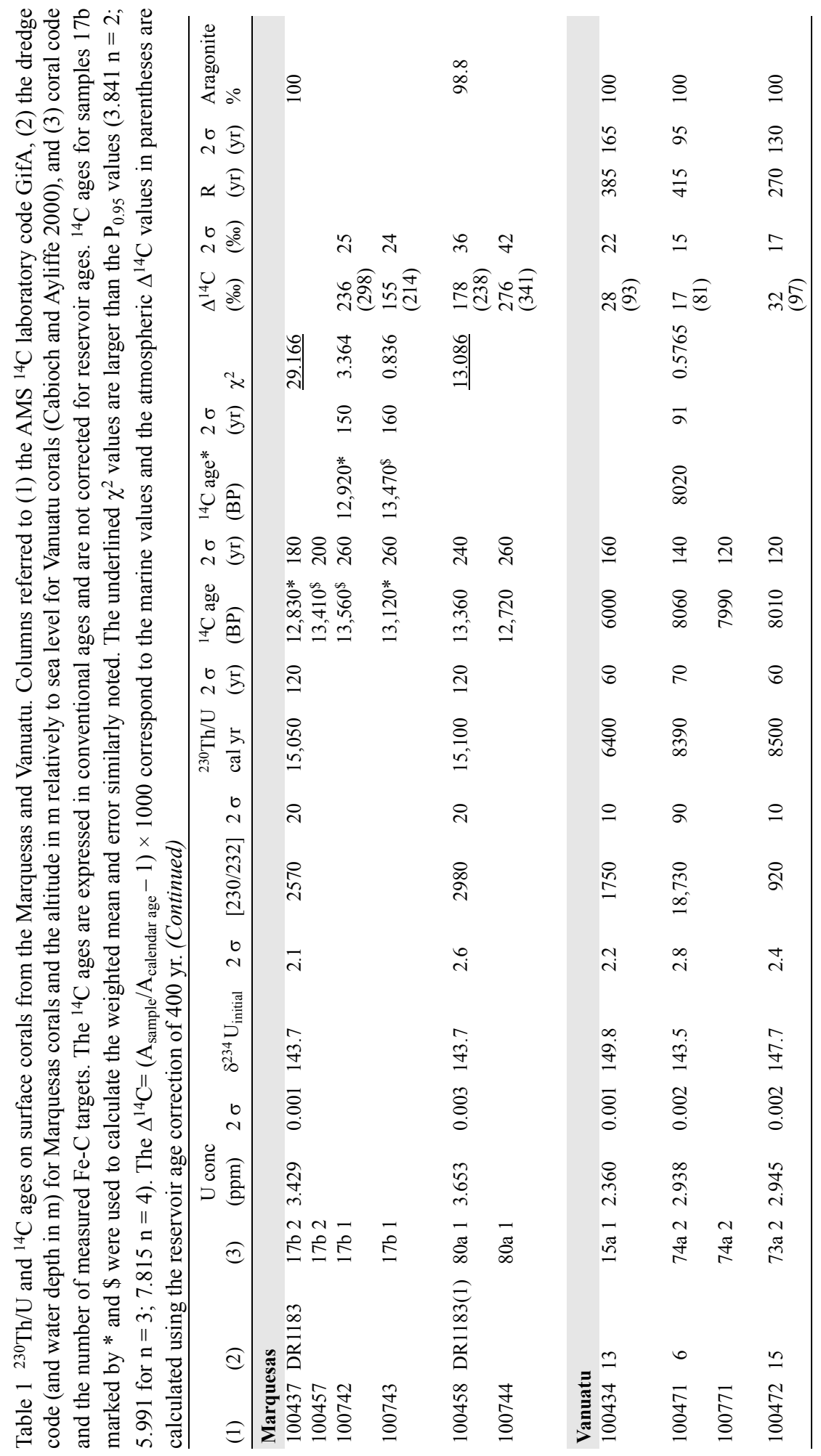




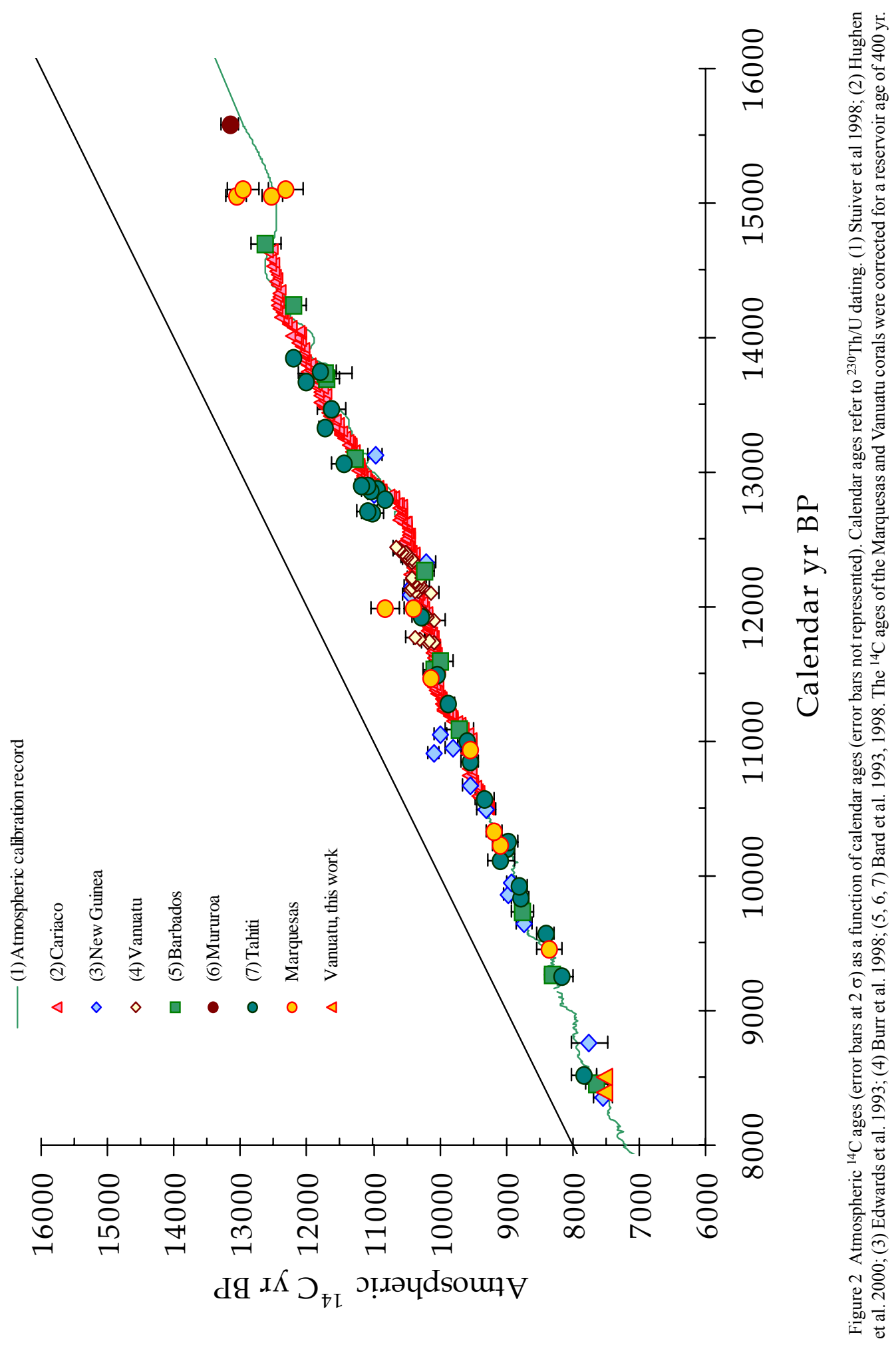


were measured with a Finnigan MAT 262 solid-source mass spectrometer using a peak jumping routine with a secondary electron multiplier. Repeated analyses of the uraninite standard HU-1 containing ${ }^{238} \mathrm{U},{ }^{234} \mathrm{U}$, and ${ }^{230} \mathrm{Th}$ in radioactive equilibrium yielded an average $\left[{ }^{234} \mathrm{U} /{ }^{238} \mathrm{U}\right]$ activity ratio of $1.0015 \pm 0.0032(\mathrm{~N}=9)\left(={ }^{234} \mathrm{U} /{ }^{238} \mathrm{U}\right.$ atomic ratio of $\left.54.98 \pm 0.18 \times 10^{-6}\right)$ and a $\left[{ }^{230} \mathrm{Th} /{ }^{238} \mathrm{U}\right]$ activity ratio of $1.0004 \pm 0.0044(\mathrm{~N}=9)$. Decay constants used in the age calculations were $\lambda^{230} \mathrm{Th}=9.1954 \times 10^{-6} \pm 7.19 \times 10^{-8} \mathrm{yr}^{-1}$ and $\lambda^{234} \mathrm{U}=.8349 \times 10^{-6} \pm 5.7 \times 10^{-9} \mathrm{yr}^{-1}$. The reported ${ }^{234} \mathrm{U} / 238 \mathrm{U}$ and ${ }^{230} \mathrm{Th} / 232 \mathrm{Th}$ activity ratios of all the dated corals were corrected for machine biases by normalization to the corresponding ratios determined for HU-1.

\section{${ }^{14} \mathrm{C}$ Dating}

Secondary crystallization in skeleton pores of corals or surface contaminants are usually eliminated by strong acid or stepwise leaching procedures (Bard et al. 1990b; Burr et al. 1992; Yokoyama et al. 2000). Such procedures are time consuming due to the partial dissolution of the sample in several aliquots and then accordingly to the increase of the number of ${ }^{14} \mathrm{C}$ measurements to check cleaning efficacy (Burr et al. 1992; Yokoyama et al. 2000). In this study, coral samples ( $20 \mathrm{mg}$ in size) were first pre-cleaned by sand blasting until the elimination of micrite forms around skeleton pores (Figure 3), which can be carefully controlled under a microscope. Under this procedure, coral samples lose between $20-60 \%$ of their initial weight. Next, the abraded coral sample is rinsed and ultrasonically cleaned and then crushed in an agate mortar. About $10 \mathrm{mg}$ of the fine powder is then immediately introduced into 1 side of a reaction vessel with 2 side arms. The coral powder is then leached in a $2-\mathrm{cm}^{3}$ solution of $\mathrm{HNO}_{3}(0.01 \mathrm{~N})$ for $15 \mathrm{~min}$ and then rinsed to neutral $\mathrm{pH}$. The second arm of the reactor is then filled with $1 \mathrm{~cm}^{3}$ of $\mathrm{H}_{3} \mathrm{PO}_{4}$ and the vessel containing the wet powder is immediately attached to the vacuum line and evacuated as suggested by Schleicher et al. 1998. After hydrolysis of the coral powder by reaction with the $\mathrm{H}_{3} \mathrm{PO}_{4}$ in vacuuo, the evolved $\mathrm{CO}_{2}$ is trapped into an ampoule. The $\mathrm{CO}_{2}$ is then reduced into graphite according to the procedure of Arnold et al. (1989).
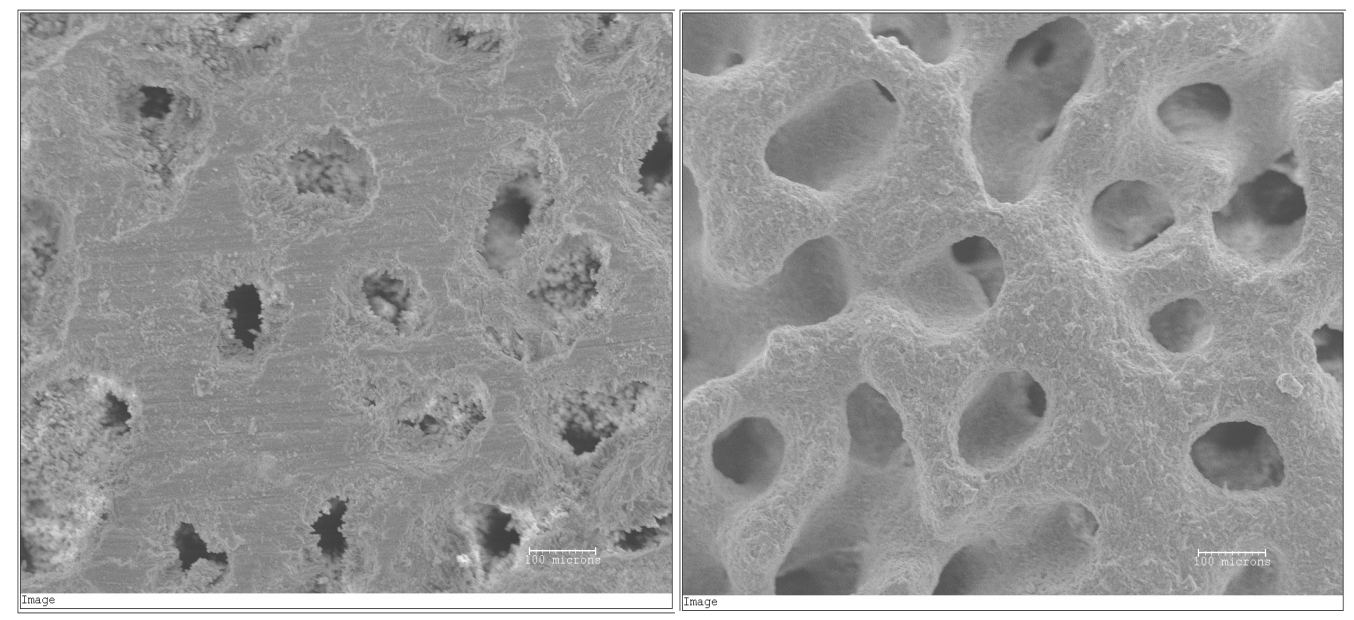

Figure 3 Scanning electron microprobe photographs of coral DR 1183 (17b) before (left) and after (right) cleaning. The sample on the right corresponds to an adjacent piece of coral treated for ${ }^{14} \mathrm{C}$ dating.

Two sub-samples were randomly picked from different parts of each coral slab and prepared independently. Given the range of growth rates observed for Porites sp. corals (Priest 1997), it is quite likely that the 2 sub-samples taken from each coral specimen grew during different seasons or years. Two targets of Fe-C powder were made from each graphite preparation in order to increase the pre- 
cision of the ${ }^{14} \mathrm{C}$ ages by accelerator mass spectrometry (AMS) at the Gif-sur-Yvette Tandétron facility (Arnold et al. 1987).

\section{RESULTS AND DISCUSSION}

\section{Evaluation of Cleaning Procedure of Corals}

The efficacy of our cleaning procedure was initially assessed through ${ }^{14} \mathrm{C}$ analyses of old corals (Table 2). In addition, we also proceeded to new ${ }^{14} \mathrm{C}$ dating of corals from Tahiti and Mururoa, previously dated by Bard et al. $(1993,1996,1998)$ (Table 3).

Blank values were assessed from 3 corals from Mururoa (Bard et al. 1993), Vanuatu (Cabioch and Ayliffe 2000), and the Marquesas, determined by ${ }^{230} \mathrm{Th} / \mathrm{U}$ dating to be beyond the limit of the ${ }^{14} \mathrm{C}$ dating method (Table 2). Although the mean and standard deviation obtained for the corals from the Marquesas and Vanuatu $(0.21 \pm 0.05$ pMC: apparent age: 49,350 $\pm 1900 \mathrm{BP})$ are slightly higher than those obtained for 1 coral (Irene 30) from Mururoa (0.16 $\pm 0.02 \mathrm{pMC}$; apparent age: 51,800 \pm 1050 $\mathrm{BP})$, they are nevertheless statistically indistinguishable from one another. The mean and standard deviation for the old ${ }^{14} \mathrm{C}$-depleted corals using this cleaning procedure are $0.20 \pm 0.05 \mathrm{pMC}$ (apparent age 50,100 $\pm 2070 \mathrm{BP}$ ) and are similar to slightly lower than those previously measured (Bard et al. 1990b; Burr et al. 1992; Yokoyama et al. 2000). The AIEA-C1 marble, currently used to assess the full procedural blank of the AMS ${ }^{14} \mathrm{C}$ dating method of our laboratory, has a value of $0.08 \pm 0.02$ pMC ( $\mathrm{n}=7$; apparent age 57,280 $\pm 2000 \mathrm{BP})$. As for the old ${ }^{14} \mathrm{C}$-depleted foraminifera reported by Schleicher et al. (1998) and Nadeau et al. (2001), the mean blank value of the old corals is larger than that of the geological $\mathrm{C} 1$ marble, which is thus inappropriate for ${ }^{14} \mathrm{C}$ age calculation of young biological materials.

Corals from Tahiti and Mururoa, previously dated between 11,000 and 17,000 cal yr (Bard et al. $1990,1993,1998)$, were subjected to our new cleaning procedure and also to that previously introduced by Bard et al. (1990b), which involved a strong HCl leach (Table 3). The $\chi^{2}$ tests for the ${ }^{14} \mathrm{C}$ ages obtained using the previous and new cleaning procedures suggest no significant differences (at the $95 \%$ confidence level) between any of them. Therefore, it appears that our new cleaning treatment is as efficient as the previous one for removing surface contaminants from such corals.

\section{Comparison of the Marine Reservoir $\boldsymbol{R}$ Ages from the Tahiti and Marquesas Corals in the Time Interval 9000-11,000 cal yr}

The ${ }^{14} \mathrm{C}$ and absolute ages of the coral sub-samples are reported in Table 1. By subtraction of the ${ }^{14} \mathrm{C}$ ages of the corals from Vanuatu and Marquesas from the corresponding atmospheric ${ }^{14} \mathrm{C}$ ages documented in the INTCAL98 tree-ring record, we estimate a reservoir age of $\sim 400 \mathrm{yr}$ for the surface of the central Pacific Ocean prior to $9000 \mathrm{cal}$ yr (Table 1). Using a similar approach between 9000 to $11,000 \mathrm{cal} \mathrm{yr}$, we determine a weighted mean $R$ value of $390 \pm 60 \mathrm{yr}$ (weighted $2 \sigma$ error; $\mathrm{n}=8$ ) for the Marquesas corals, which is close to the mean global ocean value (Stuiver et al. 1998) (Figure 4). For the same time period, a slightly lower $R$ of $280 \pm 50 \mathrm{yr}$ (weighted mean and $2 \sigma$ error; $\mathrm{n}=8$ ) is determined from the Tahiti corals. This small difference, as previously observed (Stuiver et al. 1998; Bard et al. 1998; Goslar et al. 2000), may be attributed to the location of these islands with respect to the Pacific surface water currents. While the Tahiti Islands are located in the well-ventilated South Pacific gyre, the Marquesas Islands are situated within the South Equatorial westward drift (Figure 1). The likely more extensive vertical mixing of surface waters with underlying ${ }^{14} \mathrm{C}$ depleted waters due to the Eastern Tradewinds in this region may account for the slightly older Marquesas $R$ value. 


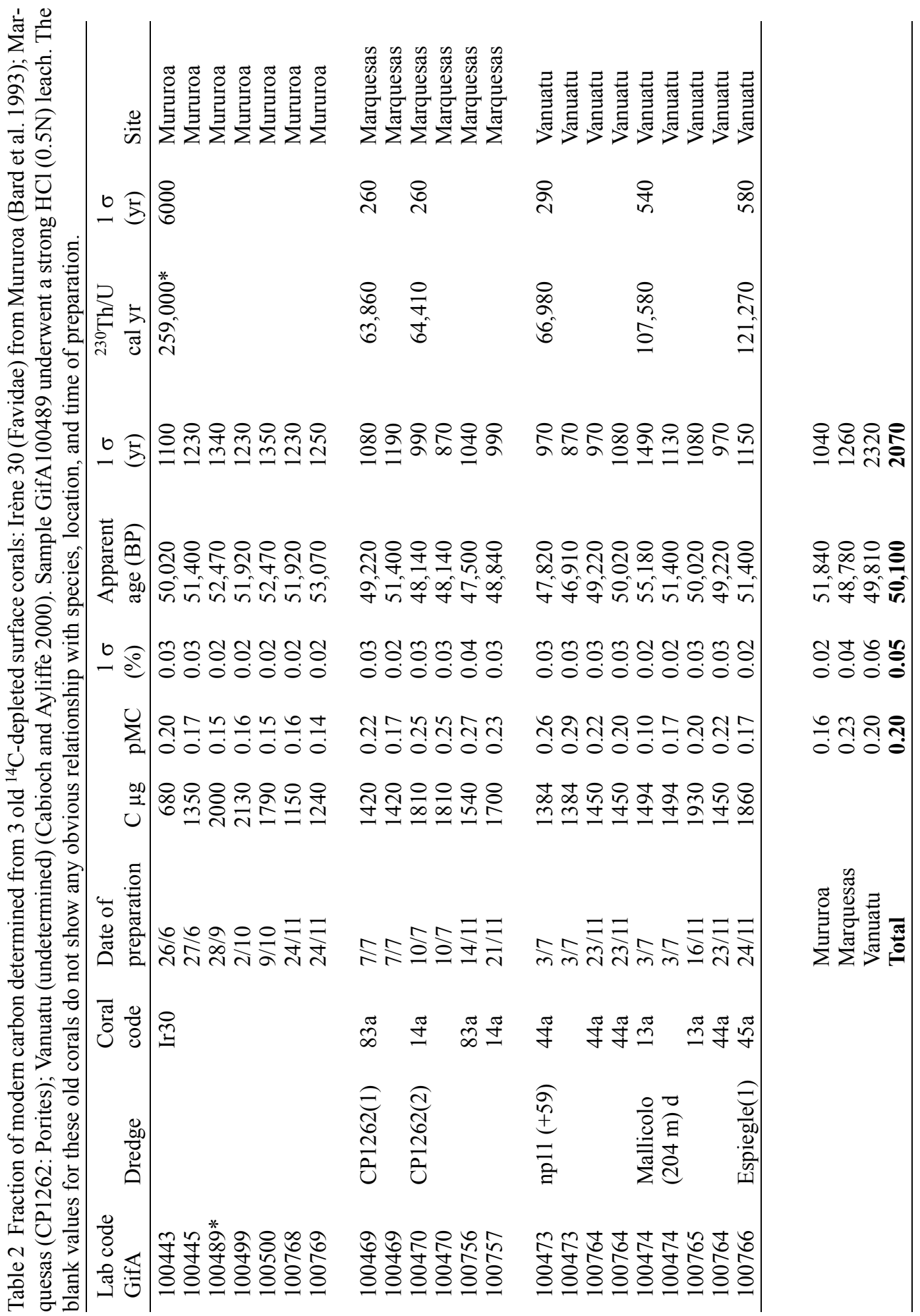


Table 3 Comparison of the ${ }^{14} \mathrm{C}$ ages of corals, obtained from different pre-cleaning procedures; $\mathrm{M}=$ mechanical sand blasting. The ${ }^{14} \mathrm{C}$ ages are given in conventional yr BP uncorrected for the reservoir age. Samples noted by an asterisk were published in Bard et al. 1998. All samples have a carbon content higher than $500 \mu \mathrm{g}$, except sample GifA100494* (340 $\mu \mathrm{g})$. The $\chi^{2}$ values for $\mathrm{P}_{0.95}$ are 3.841 for $\mathrm{n}=2 ; 5.991$ for $\mathrm{n}=3$; and 7.815 for $\mathrm{n}=4$.

\begin{tabular}{|c|c|c|c|c|c|c|c|c|c|c|}
\hline $\begin{array}{l}\text { Sample } \\
\text { code }\end{array}$ & $\begin{array}{l}\text { Lab code } \\
\text { GifA }\end{array}$ & $\begin{array}{l}\mathrm{Nr} \text { of } \\
\text { targets }\end{array}$ & $\begin{array}{l}{ }^{230} \mathrm{Th} / \mathrm{U} \\
\text { (cal yr) }\end{array}$ & $\begin{array}{l}2 \sigma \\
(\mathrm{yr})\end{array}$ & $\begin{array}{l}{ }^{14} \mathrm{C} \text { age } \\
(\mathrm{BP})\end{array}$ & $\begin{array}{l}2 \sigma \\
(\mathrm{yr})\end{array}$ & $\begin{array}{l}{ }^{14} \mathrm{C} \text { age } \\
\text { (weighted mean) }\end{array}$ & $\begin{array}{l}2 \sigma \\
(\mathrm{yr})\end{array}$ & $\chi^{2}$ test & Comment \\
\hline P7-8 & 95647* & 2 & 11,280 & 30 & 10,100 & 140 & 10,160 & 90 & 1.293 & $\mathrm{HCl}$ \\
\hline P7-8 & 100480 & 2 & & & 10,200 & 160 & & & & $\mathrm{HCl}$ \\
\hline P7-8 & 100490 & 2 & & & 10,210 & 180 & & & & $\mathrm{M}$ \\
\hline P7-9 & $95648 *$ & 2 & 11,495 & 30 & 10,280 & 140 & 10,330 & 100 & 1.542 & $\mathrm{HCl}$ \\
\hline P7-9 & 100481 & 2 & & & 10,300 & 320 & & & & $\mathrm{HCl}$ \\
\hline P7-9 & 100491 & 2 & & & 10,410 & 160 & & & & $\mathrm{M}$ \\
\hline P7-11 & $95649 *$ & 2 & 12,875 & 40 & 11,130 & 140 & 11,230 & 90 & 5.215 & $\mathrm{HCl}$ \\
\hline P7-11 & 100482 & 2 & & & 11,240 & 160 & & & & $\mathrm{HCl}$ \\
\hline P7-11 & 100492 & 2 & & & 11,390 & 180 & & & & $\mathrm{M}$ \\
\hline P7-12 & $95650 *$ & 2 & 12,800 & 30 & 11,100 & 160 & 11,130 & 90 & 5.448 & $\mathrm{HCl}$ \\
\hline P7-12 & 100483 & 2 & & & 11,270 & 160 & & & & $\mathrm{HCl}$ \\
\hline P7-12 & 100493 & 2 & & & 11,010 & 160 & & & & $\mathrm{M}$ \\
\hline P8-1 & $95654 *$ & 1 & 12,905 & 30 & 11,510 & 220 & 11,480 & 90 & 2.942 & $\mathrm{HCl}$ \\
\hline P8-1 & $96092 *$ & 2 & & & 11,540 & 140 & & & & $\mathrm{HCl}$ \\
\hline P8-1 & 100487 & 2 & & & 11,350 & 180 & & & & $\mathrm{HCl}$ \\
\hline P8-1 & 100497 & 2 & & & 115,00 & 180 & & & & $\mathrm{M}$ \\
\hline P8-2 & $95653^{*}$ & 2 & 13,335 & 30 & 11,970 & 160 & 12,030 & 80 & 4.209 & $\mathrm{HCl}$ \\
\hline P8-2 & $96091 *$ & 2 & & & 12,000 & 140 & & & & $\mathrm{HCl}$ \\
\hline P8-2 & 100486 & 2 & & & 12,190 & 180 & & & & $\mathrm{HCl}$ \\
\hline P8-2 & 100496 & 2 & & & 11,980 & 180 & & & & $\mathrm{M}$ \\
\hline P8-3 & $95652 *$ & 2 & 13,665 & 35 & 12,250 & 160 & 12,260 & 90 & 3.113 & $\mathrm{HCl}$ \\
\hline P8-3 & $96090 *$ & 2 & & & 12,350 & 140 & & & & $\mathrm{HCl}$ \\
\hline P8-3 & 100485 & 2 & & & 12,170 & 180 & & & & $\mathrm{HCl}$ \\
\hline P8-3 & 100495 & 1 & & & 12,180 & 240 & & & & $\mathrm{M}$ \\
\hline P8-4 & $95651^{*}$ & 2 & 13,850 & 35 & 12,570 & 160 & 12,490 & 90 & 6.202 & $\mathrm{HCl}$ \\
\hline P8-4 & $96087 *$ & 2 & & & 12,560 & 140 & & & & $\mathrm{HCl}$ \\
\hline P8-4 & 100484 & 2 & & & 12,350 & 200 & & & & $\mathrm{HCl}$ \\
\hline P8-4 & 100494 & 1 & & & $12,280 *$ & 280 & & & & $\mathrm{M}$ \\
\hline Mu-8-30-315 & $95656^{*}$ & 2 & 17,170 & 40 & 14,860 & 180 & 14,790 & 120 & 1.274 & $\mathrm{HCl}$ \\
\hline Mu-8-30-315 & 100488 & 1 & & & 14,690 & 280 & & & & $\mathrm{HCl}$ \\
\hline Mu-8-30-315 & 100498 & 1 & & & 14,750 & 200 & & & & $\mathrm{M}$ \\
\hline
\end{tabular}




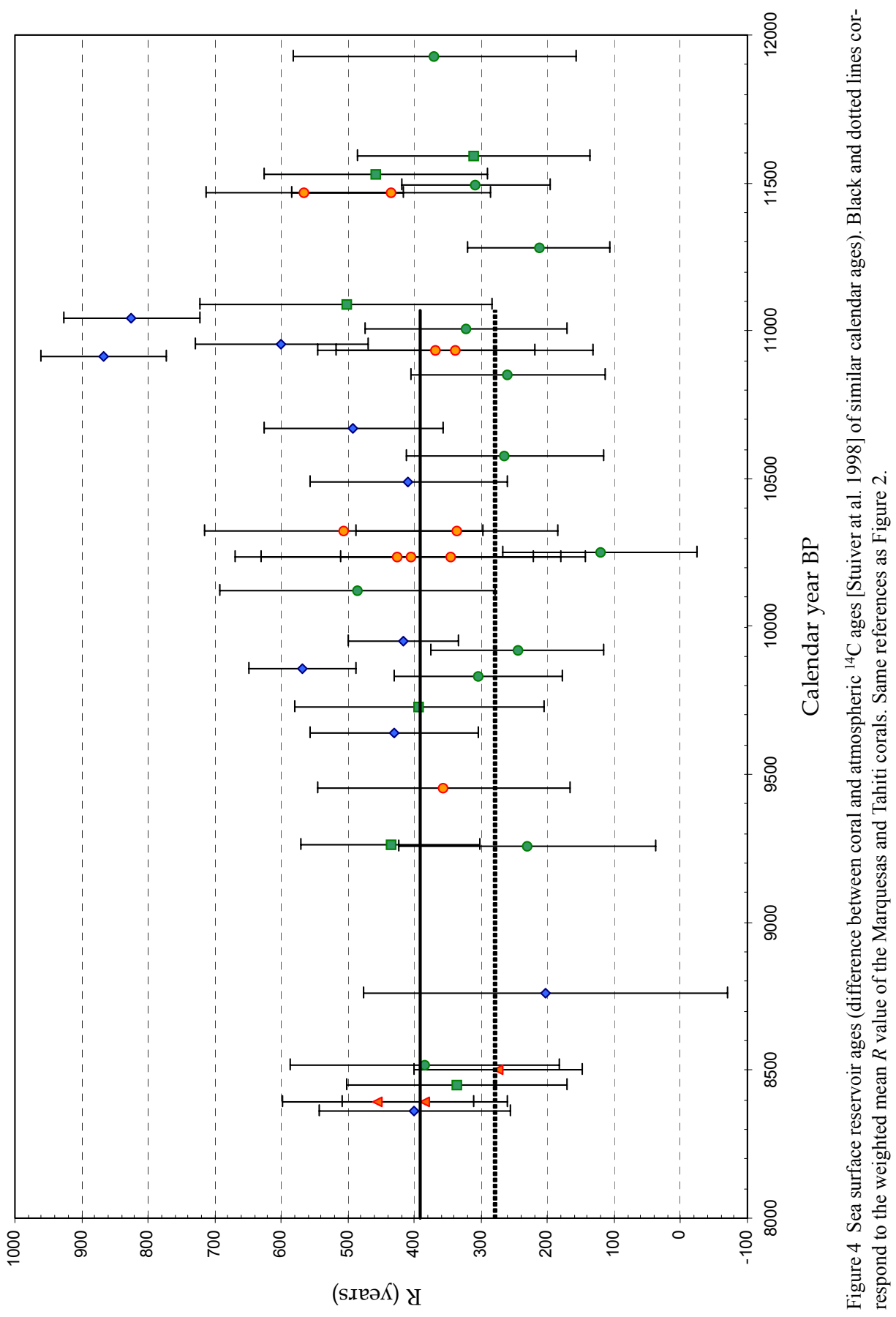




\section{Comparison of the ${ }^{14} \mathrm{C}$ Ages and $\Delta^{14} \mathrm{C}$ Values from the Marquesas and Vanuatu with Previous Marine and Atmospheric ${ }^{14} \mathrm{C}$ Record}

Between $3000 \mathrm{cal} \mathrm{yr}$ and $11,500 \mathrm{cal} \mathrm{yr}$, the ${ }^{14} \mathrm{C}$ ages are very reproducible within each coral (Table 1). Using an $R$ value of $400 \mathrm{yr}$, the estimates of the difference between the absolute and ${ }^{14} \mathrm{C}$ ages are in agreement with previous determinations (Stuiver et al. 1998; Burr et al. 1998; Edwards et al. 1993; Bard et al. 1993, 1998) (Figures 2, 5, 6). Beyond 11,500 cal yr, 2 corals dated at 12,000 and $\sim 15,100 \mathrm{cal}$ yr, however, present scattered ${ }^{14} \mathrm{C}$ values.

The 2 sub-samples of coral specimen DR1183(2) dated at 12,000 cal yr gave significantly different ${ }^{14} \mathrm{C}$ ages at the $95 \%$ confidence level (Table 1 ), with the marine or atmospheric $\Delta{ }^{14} \mathrm{C}$ values of these 2 sub-samples varying by some 50\%. Two slabs from a single coral specimen (DR 1183 and DR 1183 [1]) were dated each at $\sim 15,100 \mathrm{cal}$ yr by the ${ }^{230} \mathrm{Th} / \mathrm{U}$ method and were sub-sampled for the ${ }^{14} \mathrm{C}$ dating (Figure 7). While the $2{ }^{230} \mathrm{Th} / \mathrm{U}$ dates are very similar, the ${ }^{14} \mathrm{C}$ dates by contrast are highly scattered (Figures 2, 5, 6; Table 1). The ${ }^{14} \mathrm{C}$ ages of the sub-samples within each slab present the same range of variations from approximately 12,800 to $\sim 13,400 \mathrm{yr}$, corresponding to marine $\Delta^{14} \mathrm{C}$ values of $250 \pm 35 \%$ to $160 \pm 55 \%$ o $(2 \sigma)$, respectively. They are all within error $(2 \sigma)$ of the marine and atmospheric INTCAL98 values (Stuiver et al. 1998) (Figures 5, 6). Only the upper $\Delta^{14} \mathrm{C}$ values at $\sim 310 \%$, corresponding to the youngest ${ }^{14} \mathrm{C}$ ages, are consistent with those of the atmospheric ${ }^{14} \mathrm{C}$ record from Lake Suigetsu (Kitagawa and van der Plicht 2000) (Figures 2, 4, 5). Similarly, at 12,000 cal yr, only the largest $\Delta^{14} \mathrm{C}$ value (Figures 5,6) agrees well with those of the ${ }^{14} \mathrm{C}$ INTCAL98 calibration record (Stuiver et al. 1998) and with those from the Lake Suigetsu ${ }^{14} \mathrm{C}$ record (Kitagawa and van der Plicht 2000). Therefore, the addition of modern carbon either during the different steps of AMS ${ }^{14} \mathrm{C}$ dating procedure and/or during recrystallization processes with seawater seems unlikely. This is also attested by the very low content of magnesian $(\mathrm{Mg})$ calcite in the corals. The initial ${ }^{234} \mathrm{U} /$ ${ }^{238} \mathrm{U}$ ratios of all the corals analyzed are very similar to that of sub-modern corals at $\sim 145 \%$ o (in Delanghe et al. 2002) and within $\pm 5 \%$ of the modern seawater values (Henderson et al. 1999; Delanghe et al. 2002) (Table 1). The detrital Th contents are very low. Thus, little post-depositional alteration or recrystallization of the primary coralline aragonite has taken place. In-situ dissolution processes alone may also be ruled out, as the U concentrations of these 2 corals, DR1183(2) and DR1183(1)/DR1183, are among the largest of the measured ones (Table 1). Therefore, the ${ }^{230} \mathrm{Th} / \mathrm{U}$ dates may be considered as most likely valid.

The anomalous ${ }^{14} \mathrm{C}$ data at $\sim 12,000$ and $\sim 15,000$ cal yr would be the low $\Delta{ }^{14} \mathrm{C}$ values, and thus the old ${ }^{14} \mathrm{C}$ ages when compared to the determined atmospheric ones from Lake Suigetsu (Kitagawa and van der Plicht 2000) (Figures 2,6). This may be related to a subtle submarine diagenesis, which would include here dissolution of old carbonates and secondary Mg-calcite precipitation. Due to organic matter degradation, coral pore waters have a lower $\mathrm{pH}$ than that of open reef waters (Enmar et al. 2000) that may favor dissolution of carbonates. Secondary precipitation of aragonite and/or Mg-calcite micrites or needles of some $10 \mu \mathrm{m}$ often fill voids in skeleton pores of sub-marine fossil corals (Enmar et al. 2000) (Figure 3). A 10\% result in weight of secondary crystallization deriving from old ${ }^{14} \mathrm{C}$-depleted carbonates would account for the anomalously old ${ }^{14} \mathrm{C}$ ages at $15,100 \mathrm{cal} \mathrm{yr}$ and $5 \%$ at $12,000 \mathrm{cal}$ yr. Such a parallel contamination by "old" marine uranium with ${ }^{234} \mathrm{U} /{ }^{238} \mathrm{U}$ activity of 1.1, close to the value found in last interglacial corals at the time of deposition, would lead to a slight decrease of the $\delta^{234} \mathrm{U}_{\text {initial }}$ from the value of 149 to $\sim 144 \%$. This may explain the slightly lower $\delta^{234} \mathrm{U}_{\text {initial }}$ values of these 2 corals with respect to those of the other corals, although the difference is not significant at the $95 \%$ confidence level (Table 1). However, this represents a very extreme case, and in the marine environment, the diagenetic changes in corals with recrystallization and secondary aragonite or Mg-calcite precipitation within seawater are usually related to increasing $\delta^{234} U_{\text {initial }}$ values (Bar-Matthews et al. 1993). 


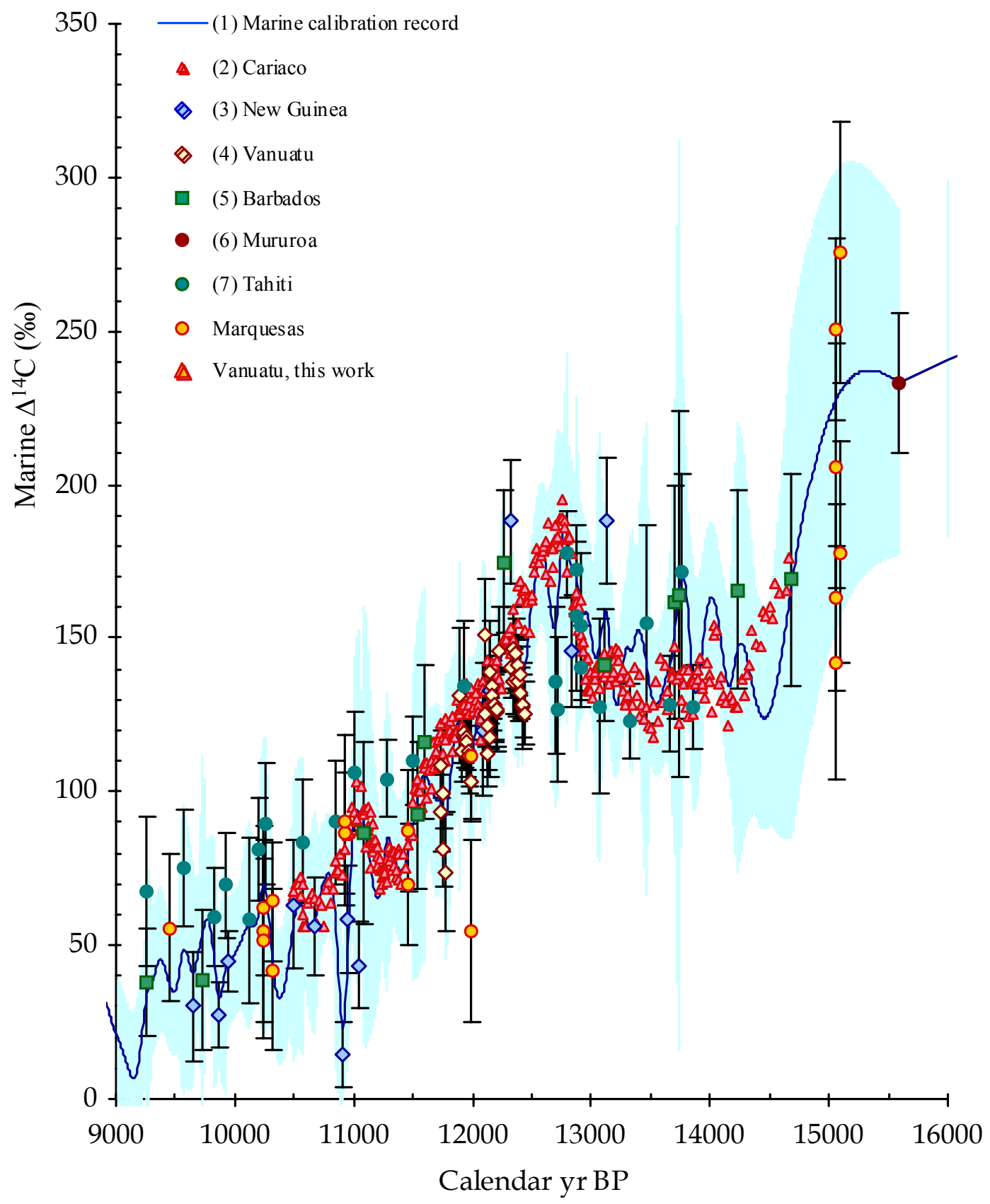

Figure 5 Marine $\Delta^{14} \mathrm{C}$ changes at the 2- $\sigma$ confidence level as a function of calendar ages. The blue envelope figured out the 2- $\sigma$ error of the marine INTCAL98 $\Delta^{14} C$ values. (1) Stuiver et al 1998; (2) Hughen et al. 2000; (3) Edwards et al. 1993; (4) Burr et al. 1998; $(5,6,7)$ Bard et al. 1993, 1998. Same references as Figure 2.

The corals dated at $\sim 12,000$ and $\sim 15,100$ cal yr were sampled in the same dredge (DR1183: $8^{\circ} 45.5^{\prime} \mathrm{S} ; 140^{\circ} 03.8^{\prime} \mathrm{W}$ ) and would reflect local and brief changes of the seawater chemical composition in the vicinity of Marquesas. Seasonal to annual variability of ${ }^{14} \mathrm{C}$ ages, which can be 


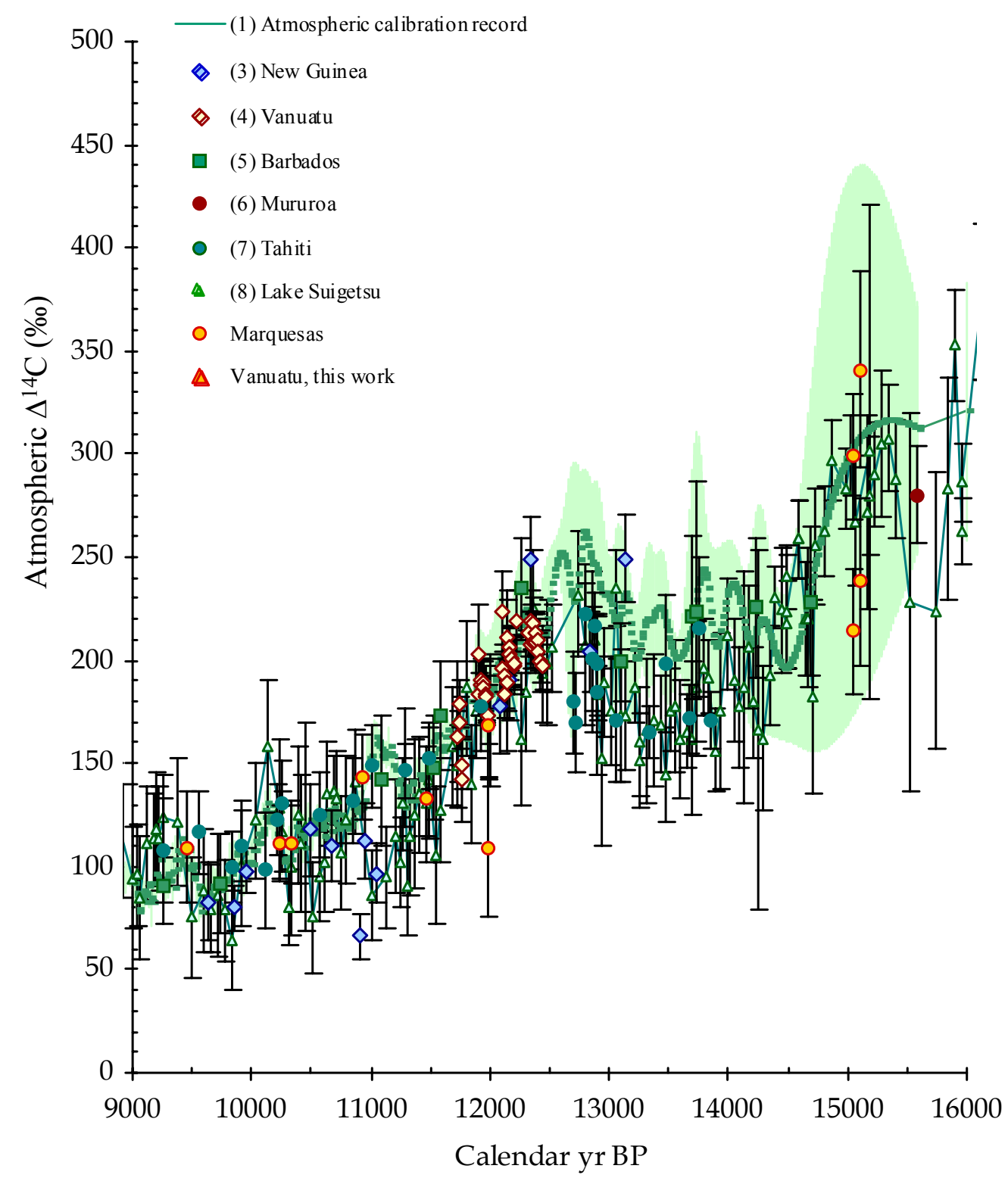

Figure 6 Atmospheric $\Delta{ }^{14} \mathrm{C}$ changes at the $2-\sigma$ confidence level as a function of calendar ages. The green envelope figured out the $2-\sigma$ error of the atmospheric INTCAL98 $\Delta{ }^{14} \mathrm{C}$ values. (8) Lake Suigetsu record (Kitagawa and van der Plicht 2000). Same references as Figure 2.

approached from our random sampling, was observed in modern banded coral samples from the Pacific Ocean (Brown et al. 1993; Druffel and Griffin 1993; Guilderson and Schrag 2001). Such variability was attributed to changes in the extent and intensity of the equatorial Pacific upwelling. However, this natural ${ }^{14} \mathrm{C}$ variability did not exceed $10-15 \%$ (Druffel and Griffin 1993), which is significantly lower than the $\Delta^{14} \mathrm{C}$ changes we observed in the fossil Marquesas corals. Thus, causes of the variation of the ${ }^{14} \mathrm{C}$ ages in these corals remain a puzzling question. 


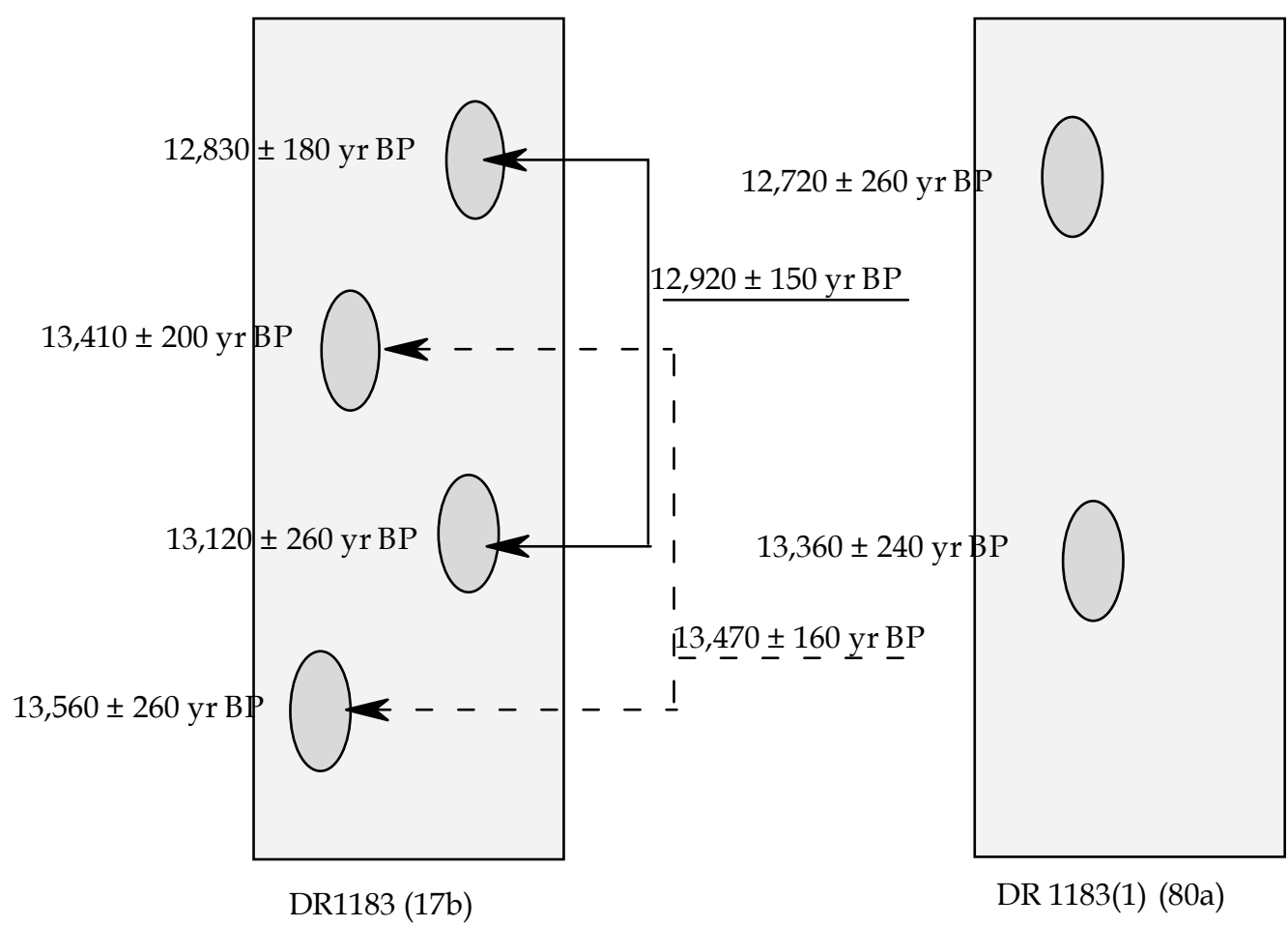

Figure 7 Sketch of 2 slabs, DR1183 and DR1183(1), of the same coral which was sub-sampled for AMS ${ }^{14} \mathrm{C}$ dating. The weighted mean of the ${ }^{14} \mathrm{C}$ ages and the weighted $2 \sigma$ from DR1183 (Table 1) are underlined.

\section{CONCLUSION}

Paired ${ }^{14} \mathrm{C}$ and ${ }^{230} \mathrm{Th} / \mathrm{U}$ dating of corals from the Marquesas and Vanuatu provide additional estimates of the difference between the absolute and ${ }^{14} \mathrm{C}$ ages of marine biogenic materials. These estimates are in agreement with those determined in previous studies between 3000 and 11,500 cal yr (Edwards et al. 1993; Stuiver et al. 1998; Bard et al. 1990a, 1993, 1998; Burr et al. 1998; Hughen et al. 2000; Kitagawa and van der Plicht 2000). Over this time interval, the reservoir age of the surface waters from the Marquesas differ by $100 \mathrm{yr}$ from $R$ values of corals from Tahiti. This is compatible with previous suggestions that variations of $R$ exist in the Pacific Ocean (Stuiver et al. 1998; Goslar et al. 2002).

Among all the corals analyzed, 2 of them from the Marquesas dated at $\sim 12,000$ and $\sim 15,000 \mathrm{cal}$ yr present scattered ${ }^{14} \mathrm{C}$ ages during the period of coral growth. Such variability may be related to rapid changes of the ${ }^{14} \mathrm{C}$ content of the surface waters around the Marquesas or to a subtle submarine diagenesis. Additional coupled ${ }^{14} \mathrm{C}$ and ${ }^{230} \mathrm{Th} / \mathrm{U}$ dating of corals from the Pacific should refine our knowledge of the extent and magnitude of these rapid changes in surface ${ }^{14} \mathrm{C}$ in this region, and will be important in understanding the underlying mechanism responsible for such fluctuations.

\section{ACKNOWLEDGEMENTS}

We acknowledge M Fontugne, L Turpin, JL Reyss, N Frank, and E Michel for helpful comments and $\mathrm{S}$ Bondevik for his helpful review. This work received the financial support of the Commissariat à l'Energie Atomique and of the Centre National de la Recherche Scientifique, and partly from the 
INSU- Eclipse program. L Ayliffe received financial support from the CNRS and the CEA. We wish to thank the captain, R Proner, and the crew of the R/V IRD Alis for their efficiency during the cruise in Marquesas. Our thanks are extended to S Caquineau and H Boucher (IRD Bondy) for X-ray diffractometry analysis. This is LSCE contribution 1100.

\section{REFERENCES}

Arnold M, Bard E, Maurice P, Duplessy JC. 1987. C-14 dating with the Gif sur Yvette Tandetron accelerator: status report. Nuclear Instruments and Methods in Physics Research B 29:120-3.

Arnold M, Bard E, Maurice P, Valladas H, Duplessy JC. 1989. ${ }^{14} \mathrm{C}$ dating with the Gif-sur-Yvette Tandetron accelerator: status report and study of isotopic fractionation in the sputter ion source. Radiocarbon 31(3): 284-91.

Bard E. 1988. Correction of accelerator mass spectrometry ${ }^{14} \mathrm{C}$ ages measured in planktonic foraminifera: paleoceanographic implications. Paleoceanography 3: 635-45.

Bard E, Arnold M, Fairbanks RG, Hamelin B. 1990a. Calibration of the ${ }^{14} \mathrm{C}$ timescale over the past 30,000 years using mass spectrometric U-Th ages from Barbados corals. Nature 345:405-10.

Bard E, Hamelin B, Fairbanks RG, Zindler A, Arnold M, Mathieu G. 1990b. U/Th and ${ }^{14} \mathrm{C}$ ages of corals from Barbados and their use for calibrating the ${ }^{14} \mathrm{C}$ timescale beyond 9000 years BP. Nuclear Instruments and Methods in Physics Research B 52:461-8.

Bard E, Arnold M, Fairbanks RG, Hamelin B. 1993 ${ }^{230} \mathrm{Th}-{ }^{234} \mathrm{U}$ and ${ }^{14} \mathrm{C}$ ages obtained by mass spectrometry on corals. Radiocarbon 35(1):191-9.

Bard E, Arnold M, Mangerud J, Paterne M, Labeyrie L, Duprat J, Mélières M, Sonstegaard E, Duplessy JC. 1994. The North Atlantic atmosphere-sea surface ${ }^{14} \mathrm{C}$ gradient during the Younger Dryas climatic event Earth and Planetary Science Letters 126:275-87.

Bard E, Arnold M, Hamelin B, Tisnerat-Laborde N, Cabioch G. 1998. Radiocarbon calibration by means of mass spectrometric ${ }^{230} \mathrm{Th} /{ }^{234} \mathrm{U}$ and ${ }^{14} \mathrm{C}$ ages of corals: an updated database including samples from Barbados, Mururoa and Tahiti. Radiocarbon 40:1085-92.

Bar-Matthews M, Wasserburg GJ, Chen JH. 1993. Diagenesis of fossil coral skeletons: correlation between trace elements, textures and ${ }^{234} \mathrm{U} /{ }^{238} \mathrm{U}$. Geochemica et Cosmochimica Acta 57:257-76.

Beck JW, Richards DA, Edwards RL, Silverman BW, Smart PL, Donahue DJ, Hererra-Osterheld S, Burr GS, Calsoyas L, Jull AJT, Biddulph D. 2001. Extremely large variations of atmospheric ${ }^{14} \mathrm{C}$ concentration during the Last Glacial period. Science 292:24537.

Burr GS, Edwards RL, Donahue DJ, Druffel ERM, Taylor FW. 1992. Mass spectrometric ${ }^{14} \mathrm{C}$ and U-Th measurements in coral. Radiocarbon 34(3):611-8.

Burr GS, Beck WJ, Taylor FW, Recy J, Edwards LR, Cabioch G, Corrège T, Donahue DJ, O’Malley JM. 1998.
A high-resolution radiocarbon calibration between 11,700 and 12,400 calendar years BP derived from ${ }^{230} \mathrm{Th}$ ages of corals from Espiritu Santo island, Vanuatu. Radiocarbon 40(3):1093-1105.

Cabioch G, Ayliffe LK. 2001. Raised coral terraces at Malakula, Vanuatu, southwest Pacific, indicate high sea level during marine isotope stage 3. Quaternary Research 56:357-65.

Druffel ERM, Griffin S. 1993. Large variations of surface ocean radiocarbon: evidence of circulation changes in the southwestern Pacific. Journal of Geophysical Research 98:20,249-59.

Edwards RL, Beck JW, Burr GS, Donahue DJ, Chappell JMA, Bloom AL, Druffel ERM, Taylor FW. 1993. A large drop in atmospheric ${ }^{14} \mathrm{C} /{ }^{12} \mathrm{C}$ and reduced melting in the Younger Dryas, documented with ${ }^{230} \mathrm{Th}$ ages of corals. Science 260:962-8.

Enmar R, Stein M, Bar-Matthews M, Sass E, Katz A, Lazar B. 2000. Diagenesis in live corals from the Gulf of Aqaba. I. The effect on paleo-oceanography tracers. Geochimica et Cosmochimica Acta 64:3123-32.

Franck N, Paterne M, Ayliffe L, van Weering T, Henriet JP, Blamart D. 2004. Eastern North Atlantic deep-sea corals: tracing upper intermediate water $\Delta^{14} \mathrm{C}$ during the Holocene. Earth and Planetary Science Letters 219:297-309.

Goslar T, Arnold M, Tisnérat-Laborde N, Hatté C, Paterne M, Ralska-Jasiewiczona M. 2000. Radiocarbon calibration by means of varves versus ${ }^{14} \mathrm{C}$ ages of terrestrial macrofossils from Lake Gościąż and Lake Perespilno, Poland. Radiocarbon 42(3):335-48.

Guilderson TP, Schrag DP. 1998. Abrupt shift in subsurface temperatures in the tropical Pacific associated with changes in El Niño. Science 281:240-3.

Henderson GM, Slowey NC, Haddad GA 1999. Fluid flow through carbonates platforms: constraints from ${ }^{234} \mathrm{U} /{ }^{238} \mathrm{U}$ and $\mathrm{Cl}-$ in Bahamas pore-waters. Earth and Planetary Science Letters 169:99-111.

Hughen KA, Overpeck JT, Lehman SJ, Kashgarian M, Southon J, Peterson LC, Alley R, Sigman DM. 1998. Deglacial changes in ocean circulation from an extended radiocarbon calibration. Nature 391:65-8.

Hughen KA, Overpeck JT, Lehman SJ, Kashgarian M, Southon J, Peterson LC. 1998. A new ${ }^{14} \mathrm{C}$ calibration data set for the last deglaciation based on marine varves. Radiocarbon 40(1):483-94.

Kitagawa H, van der Plicht J. 1998. Atmospheric radiocarbon calibration to 45,000 yr BP: Late Glacial fluctuations and cosmogenic isotope production. Science 279:1187-90 
Kitagawa H, van der Plicht J. 2000. Atmospheric radiocarbon calibration beyond 11,900 cal BP from Lake Suigetsu laminated sediments. Radiocarbon 42(3): 369-80.

Nadeau MJ, Grootes PM, Voelker A, Bruhn F, Duhr A, Oriwall A. 2001. Carbonate ${ }^{14} \mathrm{C}$ background: does it have multiple personalities? Radiocarbon 43(1):169 76.

Priess K. 1997. La croissance des Porites spp. du groupe lobata-lutea-solida (scléractiniaires massifs) dans le lagon de Mayotte (NO Canal de Mozambique). Etude sclérochronologique [PhD dissertation]. Université de la Méditerranée. $170 \mathrm{p}$.

Schleicher M, Grootes PM, Nadeau MJ, Schoon A. 1998. The carbonate ${ }^{14} \mathrm{C}$ background and its components at the Leibniz AMS facility. Radiocarbon 40(1):85-93.

Siani G, Paterne M, Michel E, Sulpizio R, Sbrana A, Arnod M, Haddad G. 2001. Mediterranean sea surface radiocarbon reservoir age changes since the Last Glacial Maximum. Science 294:1917-20.

Sikes E, Samson CR, Guilderson TP, Howard WR. 2000. Old radiocarbon ages in the southwest Pacific Ocean during the last glacial period and deglaciation. Nature 405:555-9.

Stirling CH, Esat TM, McCulloch MT, Lambeck K. 1995. High-precision U-series dating of corals from Western Australia and implications for the timing and duration of the last Interglacial. Earth and Planetary Science Letters 135:115-30.

Stuiver M, Reimer PJ, Bard E, Beck WJ, Burr GS, Hughen KA, Kromer B, McCormac G, van der Plicht J, Spurk M. 1998. INTCAL98 radiocarbon age calibration, 24,000-0 cal BP. Radiocarbon 40(3):104183.

Voelker AHL, Sarnthein M, Grootes PM, Erlenkeuser H, Laj C, Mazaud A, Nadeaeu MJ, Schleicher M. 1998. Correlation of marine ${ }^{14} \mathrm{C}$ ages from the Nordic Seas with the GISP2 isotope record: implications for ${ }^{14} \mathrm{C}$ calibration beyond $25 \mathrm{ka}$ BP. Radiocarbon 40(1):51734.

Yokoyama Y, Esat TM, Lambeck K, Fifield LK. 2000. Last ice age millennial scale climate changes recorded in Huon Peninsula corals. Radiocarbon 42(3):383401. 